\title{
What does the literature say about business groups and pyramidal ownership in the period of 1960-2018?
}

\section{Silvia Amélia Mendonça Flores}

Universidade Federal de Santa Maria, Programa de Pós-Graduação em Administração, Avenida Roraima 1000, Santa Maria, RS, Brazil.

Universidade Federal do Pampa, Rua Barão do Triunfo 1048, Santana do Livramento, RS, Brazil.

silviaamflores@gmail.com

ORCID: 0000-0002-0424-8375

Wesley Vieira da Silva

Universidade Federal de Santa Maria, Programa de Pós-Graduação em Administração, Avenida Roraima 1000, Santa Maria, RS, Brazil.

ORCID: 0000-0001-5354-8676

Igor Bernardi Sonza

Universidade Federal de Santa Maria, Programa de Pós-Graduação em Administração, Avenida Roraima 1000, Santa Maria, RS, Brazil.

ORCID: 0000-0001-5403-3279

\begin{abstract}
This paper aims to analyze the results of the research in pyramidal structures within the scope of the business groups, based on a systematic literature review. The research was conducted on two large-scale journals databases (Web of Science and Scopus), using VOSviewer, HistCite ${ }^{\mathrm{TM}}$, and Iramuteq software. The textual corpus is consisting of 65 articles and 137 authors and co-authors. Bae et al. (2002) and Almeida and Wolfenzon (2006) are the most influential for the research fields. We infer as a conceptual framework that searches in pyramidal structures are contained in the field of business groups since they represent a form of organization and representation of ownership and control. We identify as a theoretical gap the analysis of the political connections and the social role. Thus, the contributions are in the sense of presenting a panorama on the themes, supporting future researches.
\end{abstract}

Keywords: Business groups; Pyramidal ownership; Pyramidal structure; Bibliometric; Systematic Review.

\section{Introduction}

In corporate finance, ownership and control structure are associated with several aspects. La Porta et al. $(1997,1998)$ suggest that the level of the legal protection of minority shareholders relates to the type of ownership and control structure adopted by corporations. Common law countries tend to protect their shareholders more than civil law countries (Bebchuk, Kraakman, \& Triantis, 2000; Faccio, Lang, \& Young, 2001; La Porta, Lopez-desilanes, Shleifer, \& Vishny, 2000), resulting in better levels of corporate governance and corporate valuation (Chen et al. 2006; La Porta et al. 2002).

In the context, individuals or families control several companies, forming a hierarchical chain of ownership relations (Wolfenzon, 1999). Pyramidal ownership structures characterize 
this organizational format. These structures may trigger excess control (ownership of voting shares) and conflicts of interest between majority and minority shareholders (Bebchuk et al., 2000; La Porta, Lopez-de-silanes, \& Shleifer, 1999), since the final owner uses indirect ownership to maintain control over other companies (Bertrand \& Mullainathan, 2003; Khanna \& Rivkin, 2001).

In conjunction with the research on pyramidal structures, the business groups are observed. Business groups are legally separate sets of firms but bound by persistent and/or informal relationships (Granovetter, 2005). Are also defined as those networks that exhibit unrelated diversification under common ownership (Cuervo-Cazurra, 2006). They are an interesting and little explored research in the literature (Khanna, 2000), is considered a new organizational form that requires explanation. They are usually organized in pyramidal ownership structures; forming family business groups (Almeida, Park, Subrahmanyam, \& Wolfenzon, 2011; Almeida \& Wolfenzon, 2006; Bennedsen, Fan, Jian, \& Yeh, 2015; C.-N. Chung, 2004; Claessens, Djankov, \& Lang, 2000).

Despite the growing interest in pyramidal ownership structures, there is still no formal theory (Almeida \& Wolfenzon, 2006) and a good understanding of its economic role (Holmén $\&$ Högfeldt, 2009). From the perspective of business groups, it is evident its omnipresence (Almeida et al., 2011) and diversity, being a hybrid organizational form between the market and the firm, which can generate new reflections on firm theory and its limits (Khanna \& Yafeh, 2007).

This paper aims to analyze the results of the research in pyramidal structures within the scope of the business groups, based on a systematic literature review. Some research questions will guide the analysis, such as who are the specialists in the fields of research in business groups and pyramidal ownership? How have these fields developed over time? Also, what are the main topics associated with the study of business groups and pyramidal ownership? (Zupic \& Čater, 2015). The research was conducted on two large-scale journals databases, the Web of Science and Scopus.

The present state of the knowledge in the field report that the ownership of the business group is important, but discussion of this in the literature has been limited (Cuervo-Cazurra, 2006). We contribute to contemporary literature by analyzing the pyramidal ownership with the formation of business groups. In the literature, the term "business groups" is used in a diversified way (Colpan, Hikino, \& Lincoln, 2010); in sociology presupposes the formation of ties (Granovetter, 2005); in the financial studies evidence the business groups as mechanisms 
for the expropriation of minority shareholders (La Porta et al., 1998, 1997), using of pyramidal structures (La Porta et al., 1999).

A search was done in the Web of Science with the term "systematic review," refining the results by "business groups," "pyramidal ownership" and "pyramidal structure" (search string in Table 1), to identify previous works. The refinement generated two results. Only one of them performs a systematic literature review, having a different focus of the present study, i.e., analyzing the evolution of the debate on control enhancing mechanisms.

This article is structured in five sections, the first being this introduction. The second presents the theoretical reference, and the third contains the methodological procedures used. The fourth section presents the analysis and discussion of the results, and the fifth corresponds to the final remarks.

\section{Business Groups and Pyramidal Ownership}

The classic definition of groups is presented by Leff (1978), showing that economic groups represent companies that conduct business in different markets under common conditions of entrepreneurship and financial control, establishing interpersonal trust relationships. In the field of Agency Theory (Jensen \& Meckling, 1976), the ties established between the group companies are agency relationships, also occur between majority and minority shareholders (Yiu, Lu, Bruton, \& Hoskisson, 2007).

There are several denominations for business groups, which differ according to countries and regions. In Asian countries, for example, there are the chaebols in South Korea, the keiretsu in Japan, the qiye jituan in China and the guanxi qiye in Taiwan (Yiu et al., 2007). Specific denominations for business groups are also identified in other countries, such as business houses in India, economic groups in Latin American countries, groups in Spain and family holdings in Turkey (Granovetter, 2005; Yiu et al., 2007).

The interconnection between business groups and pyramid structures is made in the ownership relations of firms (Almeida \& Wolfenzon, 2006; Claessens et al., 2000; Faccio et al., 2001). Cuervo-Cazurra (2006) classified the business groups in three types, according to the characteristics of their property. They can be widely held, state-owned, and family-owned, and in the latter classification, an individual or family is involved in group ownership, control and management, and can be organized as pyramids to maintain the family control (Almeida \& Wolfenzon, 2006). 
Khanna and Yafeh (2007) proposed a taxonomy for business groups, based on three dimensions: group structure, group ownership and control, and group interaction with society. The group's structure considers horizontal diversification (group performance in different sectors), vertical integration (among group companies) and involvement in the financial sector. In the ownership and control of the group, it has the analysis of the pyramidal structure and exercising the familiar control. Finally, the group interaction with society relates to the interconnection of business groups with the State.

In the dimension of ownership and control, attention is focused on the pyramidal structures (Almeida et al., 2011). One point worth highlighting is the legal protection of shareholders (Almeida \& Wolfenzon, 2006; La Porta et al., 1999; Shleifer \& Wolfenzon, 2002). The weak legal protection favors the controller (at the top of the pyramid), who can transact resources (asset sales, transfers, among others) from bottom to top, which is called tunneling (Bertrand, Mehta, \& Mullainathan, 2002; Bertrand \& Mullainathan, 2003; Johnson, La Porta, Lopez-de-Silanes, \& Shleifer, 2000).

The pyramid structure allows for the creation of elites to control most of the corporate sectors (Morck, 2007) that can maintain control (voting rights) with a relatively small fraction of ownership (cash flow rights), creating the deviations of rights (Levy, 2009; Riyanto \& Toolsema, 2008). However, some pyramidal structures have a low level of separation between ownership and control. Almeida and Wolfenzon (2006) demonstrate an alternative model in which pyramid creation is characterized by companies that need high levels of investment and/or low profitability. Figure 1 shows a timeline, highlighting relevant studies.

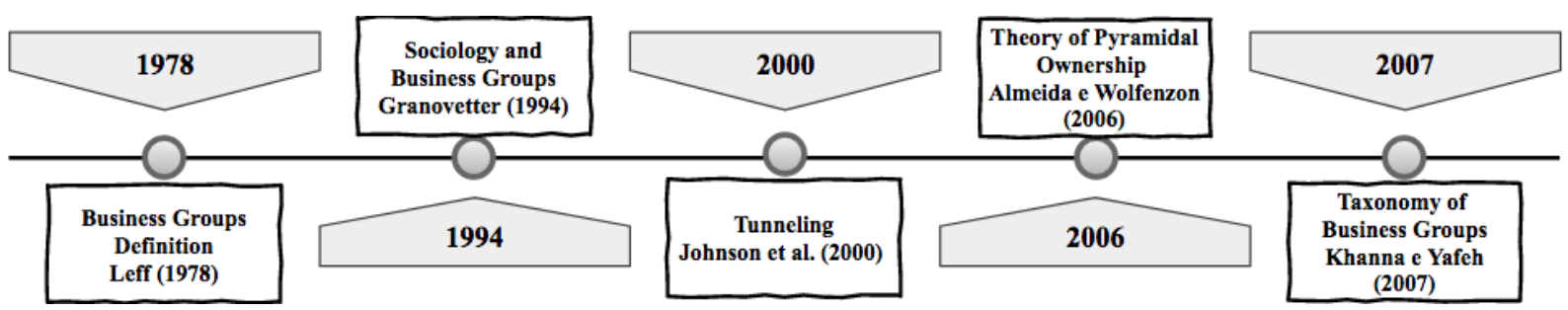

Figure 1. Timeline of the research involving Business Groups and Pyramidal Ownership Source: Draw.io - Elaborated by the authors

The timeline begins with the classic definition of business groups, as discussed by Leff (1978). In sociology, the relevance of studies by Granovetter (1994) explores the formation of business groups from economic, political, and social ties. Cross-company transactions are the focus of Johnson et al. (2000) that presents the concept of tunneling, explored in pyramidal 
structures. Next, the proposal of a theory for the pyramidal ownership (Almeida \& Wolfenzon, 2006) and taxonomy for the study of the business groups (Khanna \& Yafeh, 2007).

\section{Methods}

For the research of scientific publications concerning pyramidal ownership, the Boolean operator "or" is used to identify the use of similar terms, which correspond to "pyramidal structure." Besides, the search strings considered the word variations (singular and plural) from including the asterisk. The searches on the bases of periodicals were carried out on September 13,2018 , and the download of the results, which in the following days were filtered through the scope of the research and impact of the journal.

Table 1. Databases and search strings

\begin{tabular}{c|l}
\hline Databases & \multicolumn{1}{c}{ Search Strings } \\
\hline \multirow{5}{*}{$\begin{array}{l}\text { Web of } \\
\text { Science }\end{array}$} & $\begin{array}{l}\text { TS=("systematic* review*") Refined by: TOPIC: ("business groups" OR "pyramidal ownership" } \\
\text { OR "pyramidal structure") Stipulated time: every year. Indexes: SCI-EXPANDED, SSCI, } \\
\text { A\&HCI, CPCI-S, CPCI-SSH, ESCI. }\end{array}$ \\
\cline { 2 - 2 } & $\begin{array}{l}\text { TS=("business* groups*") Refined by: TOPIC: ("pyramidal* ownership*" OR "pyramidal* } \\
\text { structure*") AND LANGUAGES: (ENGLISH) AND TYPES OF DOCUMENTS: (ARTICLE OR } \\
\text { REVIEW) Stipulated time: 1960-2018. Indexes: SCI-EXPANDED, SSCI, A\&HCI, CPCI-S, }\end{array}$ \\
& CPCI-SSH, ESCI. \\
\hline \multirow{2}{*}{ Scopus1 } & $\begin{array}{l}\text { AITLE-ABS-KEY ("business*groups*" )) } \\
\text { AND (( "pyramidal*ownership*" OR "pyramidal*structure*" ) ) AND ( LIMIT } \\
\text { TO ( DOCTYPE, "ar" ) OR LIMIT-TO ( DOCTYPE , "re" ) ) AND ( LIMIT- } \\
\text { TO (LANGUAGE, "English")) }\end{array}$ \\
\hline
\end{tabular}

${ }^{1}$ Legend - TS: topic; ABS: abstract; KEY: Keywords; DOCTYPE: document type; ar: an article; re: a review. Source: Elaborated by the authors

Due to the amplitude of the themes, the results were refined by the research protocol with the objective of evaluating whether the selected studies really are important for the systematic literature review (Tranfield, Denyer, \& Smart, 2003). The steps for inclusion and exclusion criteria is plotted in Figure 2. 


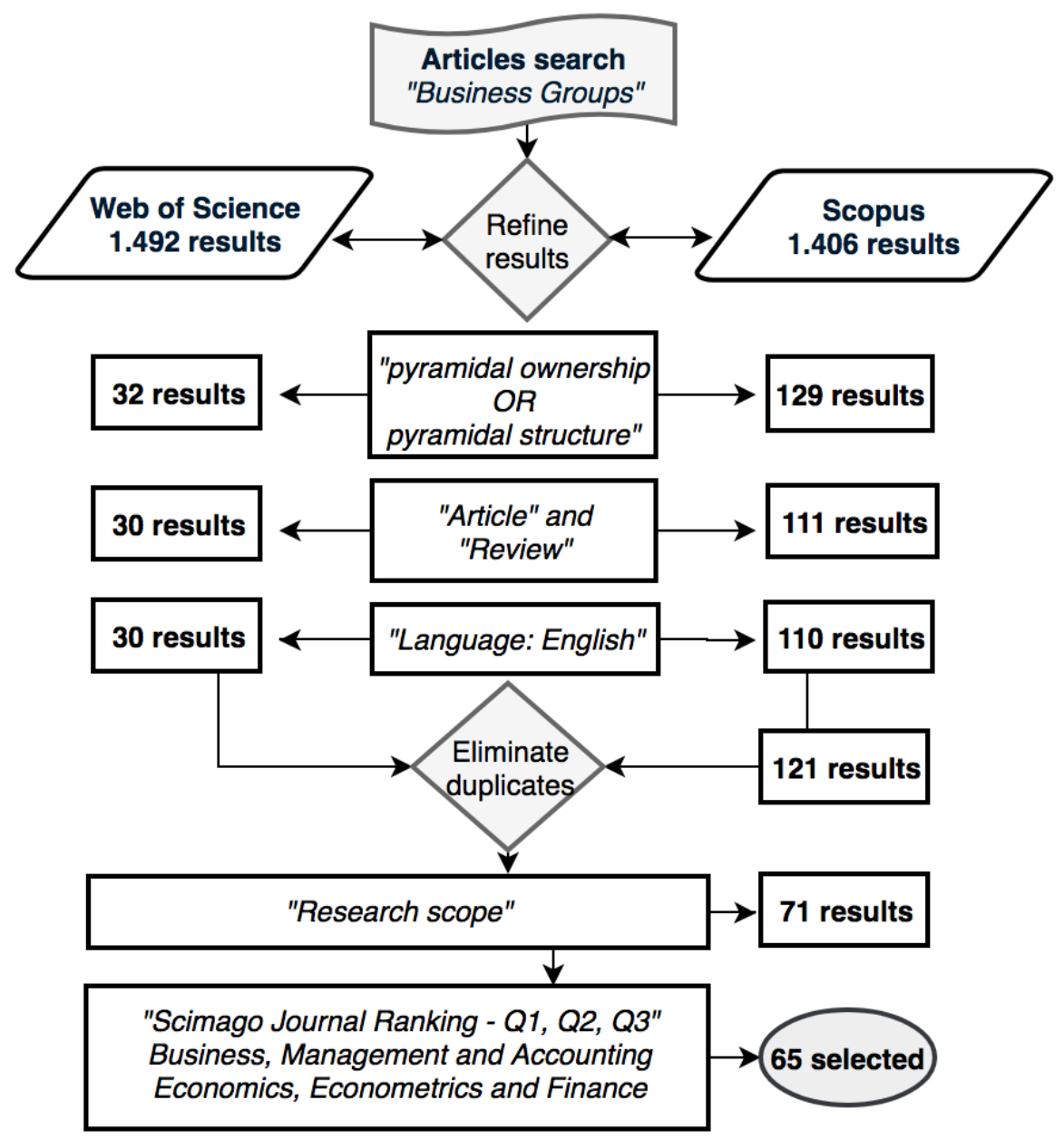

Figure 2. Systematic Literature Review steps

Source: Draw.io - Elaborated by the authors

The inclusion and exclusion criteria were used to refine the results and are defined based on the scope of the review (Zupic \& Čater, 2015). The term of the business search was refined by the topic of pyramidal ownership or pyramidal structure. In Web of Science was found 32 results and in Scopus 129 results. The filters used included articles and review and the English language, because are the lingua franca of science (Castillo-Vergara, Alvarez-Marin, \& Placencio-Hidalgo, 2018; Vallaster, Kraus, Merigó Lindahl, \& Nielsen, 2019). The duplicate results were removed, totaling 121 valid results.

After, the adherence of the results to the scope of the research was identified. The title and abstract were read, and the occurrence of the keywords (business groups, pyramidal ownership, and pyramidal structure) throughout the article was verified. The application of these filters resulted in 71 papers, which were refined by the Scimago Journal \& Country Rank (SJR), considering the first three-quarters of classification (journals with the best prestige). Thus, the textual corpus of the research comprises 65 articles. 
The research questions are answered by different bibliometric methods. To analyze of the specialists in the fields of research in business groups and pyramidal ownership we use citation analysis. The bibliometric method the co-citation analysis is used to identify how have these fields developed over time and, the main topics associated with the study of business groups and pyramidal ownership are answered by bibliographical coupling (Zupic \& Čater, 2015).

The citation analysis demonstrates the relevant publications and researchers, it does not explore the relational aspect of citations. Therefore, two other methods are used: co-citation analysis (prospective coupling) and bibliographic coupling analysis (retrospective), in the software VOSviewer (Van Eck \& Waltman, 2010).

The analysis of co-citation is understood as the frequency with which two units (documents, authors, periodicals) are cited together by a list of more current references, being exposed by Small (1973). The strength of co-citation is determined by the reaction of the scientists to the published articles (or authors) (Marshakova, 1981). The co-citation image reflects the state of the field in a dynamic way, which may change with time, thus making it a prospective method (Zupic \& Čater, 2015).

Another form of citation analysis, that is, the method of bibliographic coupling, was introduced by Kessler (1963) and showed that two works are bibliographically coupled when they refer to at least one publication in common. When measuring the proximity between articles, from the references they share, one can identify similarities, such as theoretical and methodological questions. The bibliographic coupling is still not widely used in the management area, is a method with great potential (Zupic \& Čater, 2015).

\section{Results and discussion}

We evidenced the results of the bibliometric study, based on the three laws of bibliometry: a) Lotka's Law (1926), which estimates the degree of relevance of authors in a given area of knowledge (Lotka, 1926); b) Bradford's Law (1934), which verifies the degree of reputation of periodicals (Bradford, 1934); and c) Zipf's Law (1949), which measures the frequency of occurrence and co-occurrence of words in the text (Zipf, 1949).

\subsection{Characterization of the textual corpus}


The results report a total of 65 articles, 137 authors and coauthors, distributed in 42 scientific journals over the years. The results start in the year 2002 and end in the year 2018, being characterized as more recent themes in the literature.

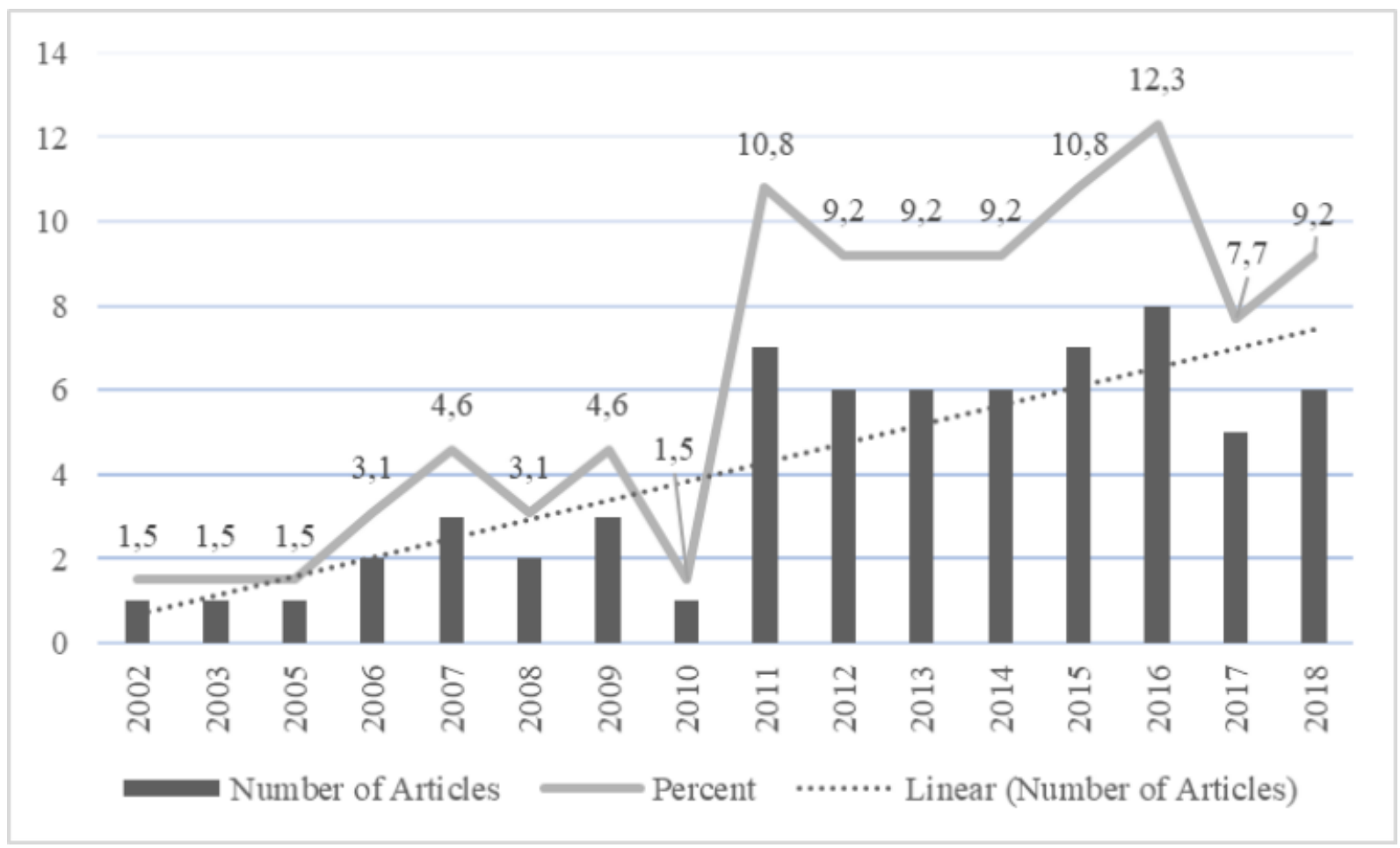

Figure 3. Temporal distribution of the textual corpus

Source: Elaborated by the authors

The time distribution, in Figure 3, reports that the publications in business groups with the topics of pyramidal structures and ownership start in the year 2002, having no results in 2004. They present a linear distribution after the year 2010. A highlight was the year 2016, with eight articles and $12.3 \%$ of the total, and the years 2011 and 2015, with seven articles and $10.8 \%$ of the textual corpus. Two articles stand out, being the main ones of the textual corpus of research. The first one is by Bae et al. (2002), titled "Tunneling or value added? Evidence from mergers by Korean business groups", published in the Journal of Finance, with a total of 391 citations. The second article is by Almeida and Wolfenzon (2006), entitled "A theory of pyramidal ownership and family business groups," and published in the Journal of Finance, with 216 citations in total.

We analyzed the number of authors per article, considering the temporal distribution. They were divided into articles with only one author, two authors, three authors, and four or more authors. The frequencies obtained by HistCite ${ }^{\mathrm{TM}}$ show that two authors developed the largest number of articles (23 papers), representing 35\% of the sample. There is a partnership between three authors (21 papers), a single author (12 papers) and four or more authors ( 9 
papers). Until the year 2010, the articles were carried out mainly by two authors, and as of 2011, articles with three authors become the main format. Also, there are works with partnerships covering publications of four or more researchers.

Afterward, the Figure 4 displays the geographic distribution of the corpus was analyzed, based on the results of HistCite ${ }^{\mathrm{TM}}$ (analyzes the country of the first author). The emphasis is on the general characterization of the work, identifying the distribution of research in 22 countries, with 101 records in total.

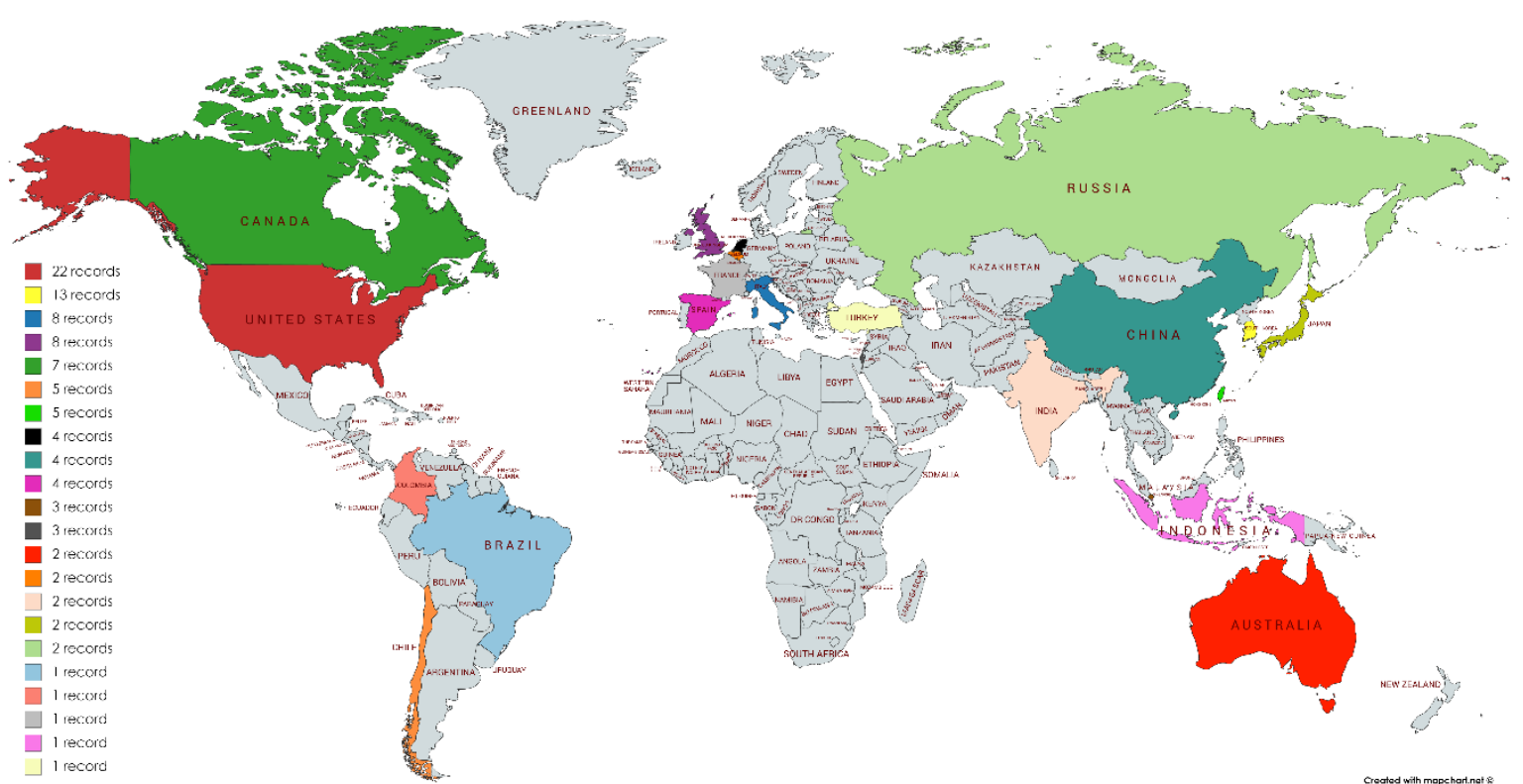

Figure 4. Distribution of the textual corpus by country

Source: Elaborated by the authors in the mapchart.net

Note: This image falls under the CC BY-SA 4.0 license (https://creativecommons.org/licenses/by-sa/4.0/).

The results show that the five most representative countries in the number of authors comprise $57.43 \%$ of the textual corpus. The United States is responsible for $21.78 \%$, with the presence of 22 records. South Korea is in second place with 13 occurrences. In this way, the influence of US research in the area of finance is confirmed. As for South Korea, the relationship between Asian countries and business groups is highlighted. The other countries have a smaller number of registries, emphasizing that many may have been produced in partnership with more representative countries.

4.2 Analysis of authors and co-authors 
We used bibliometric methods of citation, co-citation, and bibliographic coupling. Most bibliometric studies provide citation analysis to demonstrate a measure of influence since the authors cite the documents; they consider to be important (Zupic \& Čater, 2015).

The citation of documents was analyzed from the perspective of the citation indicators available in HistCite ${ }^{\mathrm{TM}}$, that is, Global Citation Score (GCS) and Local Citation Score (LCS). The GCS refers to a global criterion, which analyzes the number of citations to the document from all sources, according to data from the Web of Science database. The LCS refers to the number of citations to the article within the collection, being in this case, the textual corpus (Garfield, Pudovkin, \& Istomin, 2003).

For the analysis of the GCS, we considered as a criterion values equal to or greater than 10. The results show the connection of 25 articles, which are called "nodes." The connections between these nodes represent 35 links, with the minimum citation value equal to 11 and the maximum value equal to 391. In an analysis of representativeness, it was found that, together, the five papers of the textual corpus most cited by GCS, represent $63 \%$ of the total (25 papers selected for analysis).

Respectively, they are characterized: Bae et al. (2002) titled "Tunneling or value added? Evidence from mergers by Korean business groups", published in the Journal of Finance; Almeida and Wolfenzon (2006), entitled "A theory of pyramidal ownership and family business groups", also published in the Journal of Finance; Masulis et al. (2011) entitled "Family Business Groups around the World: Financing Advantages, Control Motivations, and Organizational Choices”, published in The Review of Financial Studies; Almeida et al. (2011), entitled "The structure and formation of business groups: Evidence from Korean chaebols", published in the Journal of Financial Economics; and Cuervo-Cazurra (2006), entitled "Business groups and their types", published in the Asia Pacific Journal of Management.

In general, these papers analyze the presence, structure, and formation of business groups, especially those controlled by families. As for the relationship with pyramidal structures, the literature on family groups predominantly studies this type of structure, which is prevalent in many markets because it facilitates the maintenance of family control.

We identified the works with higher levels of LCS, to present the most important citation links in the textual corpus. For this verification, the count limit of 15 is the criterion. This limit indicates that the 15 papers with the highest levels of internal interconnections will be displayed. Figure 5 shows the demonstration of the results in the analysis period. 


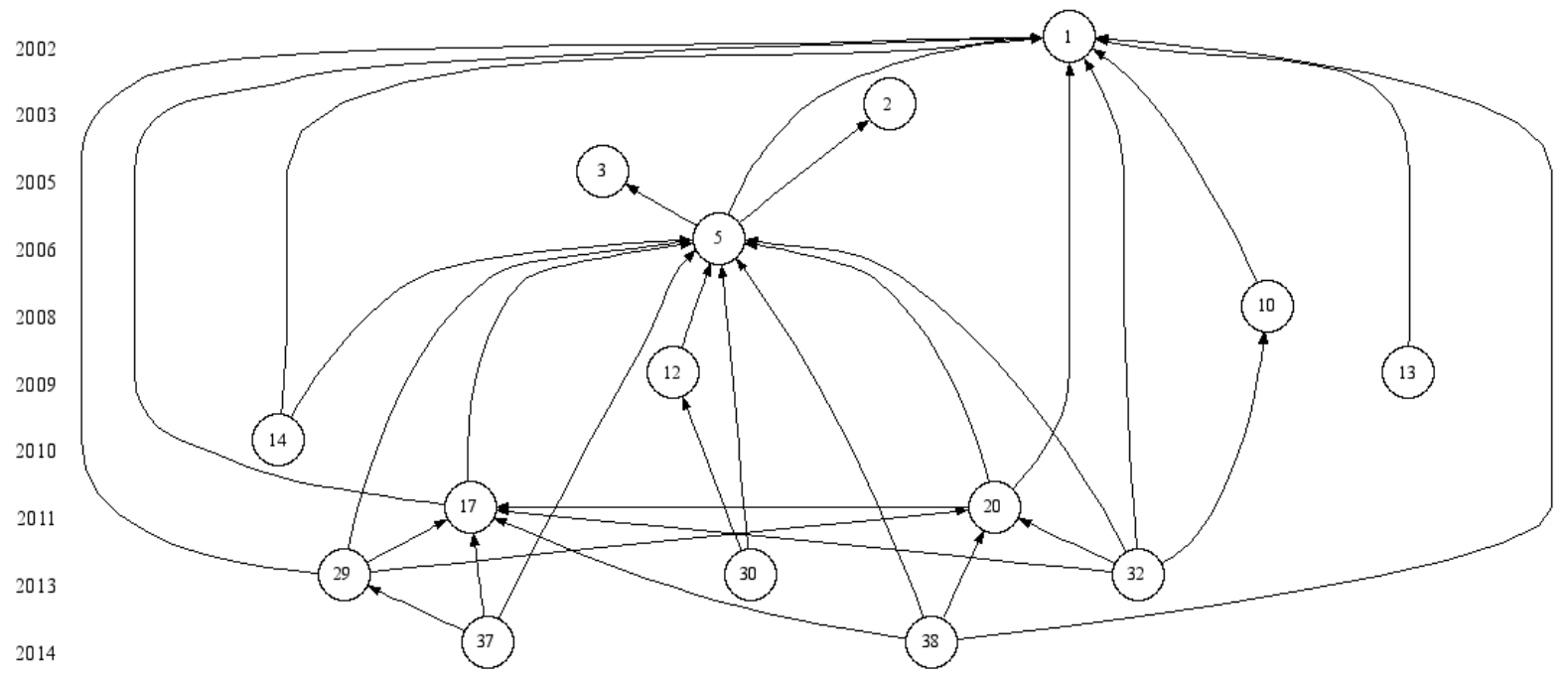

Figure 5. Local citation score network

aLegend: 1. Bae et al. (2002); 2. Demirag and Serter (2003); 3. Cestone and Fumagalli (2005); 5. Almeida and Wolfenzon (2006); 10. Bae et al. (2008); 12. Levy (2009); 13. Dow and McGuire (2009); 14. Bhaumik and Gregoriou (2010); 17. Almeida et al. (2011); 20. Masulis et al. (2011); 29. Bena and Ortiz-Molina (2013); 30. Chung (2013); 32. Byun et al. (2013); 37. Gopalan et al. (2014); 38. Buchuk et al. (2014).

Source: HistCite ${ }^{\mathrm{TM}}$ - Elaborated by the authors

The 15 papers with higher levels of local citation score form the nodes in the network, being the minimum value of 2 and the maximum value of 37 in the LCS. In general, it is noted that there is at least one interconnection between all articles. The oldest ones are also the most cited, confirming the expansion of the themes from the previous literature, which serves as the main basis for developing new research.

We concluded that in the textual corpus under analysis, the beginning of the thematic discussions comprises the paper number 1 of Bae et al. (2002), which was cited by 20 other papers also included in the corpus (9 are in Figure 5). This paper is also the most cited at the global level. Its representativeness can be attributed to the goal of exploring the nature of business groups in emerging markets (Korean Business Groups), from two competing views in the literature: the "value added view" of Khanna and Palepu (2000) and the "tunneling view" of Johnson et al. (2000). In the first one, it assumes an added value for the member firms of the business groups, while in the second it is assumed as an opportunity the transfer the wealth and benefits to the controlling shareholders. The evidence found is consistent with the tunneling view.

The paper number 5 by Almeida and Wolfenzon (2006) is the most cited by other papers of the textual corpus (LCS of 37). This work continues to be cited over time, for most of the textual corpus. The relevance is the presentation of a theory for pyramidal ownership and family business groups. The authors developed a theoretical model for pyramidal structures, which demonstrates the creation of new companies and the advantage of financing. Almeida and 
Wolfenzon (2006) also cite three other papers of the corpus, being Bae et al. (2002) to exemplify the expropriation in pyramid structures, Cestone and Fumagalli (2005) that present some benefits in the formation of business groups and that of Demirag and Serter (2003) to expose the empirical implications of pyramidal structures.

Other papers to be highlighted are those of numbers 17 and 20, with the respective authors: Almeida et al. (2011) and Masulis et al. (2011). The works were published in the same year and have an LCS of 16. According to their arrangement in Figure 5, they appear to form small clusters, connected by more recent works. In the connection between Almeida et al. (2011), Bena and Ortiz-Molina (2013) and Gopalan et al. (2014), it is noted that, despite the specific objectives of each article, there are some common discussions, as the intra-group investments and dividend policy in business groups. The connections between Masulis et al. (2011), Byun et al. (2013) and Buchuk et al. (2014) can be represented by the context of debt and the advantages of financing in pyramidal ownership and business groups.

Figure 5 shows the timeline until the year 2014, when the papers with the highest citation indicators are included. The most recent work will still be cited over time and, therefore, less representative indicators are warranted. Table 2 shows the complement of the citation analyzes, listing the 15 most relevant papers, along with their identifications and the number of global and local citations. 
Table 2. Top 15 citation documents

\begin{tabular}{|c|c|c|c|c|c|c|}
\hline Id & Document & Year & Journal & Title & GCS & LCS \\
\hline 1 & Bae, K.H; Kang, J.K; Kim, J.M. & 2002 & Journal of Finance & $\begin{array}{l}\text { Tunneling or Value Added? Evidence from Mergers by Korean } \\
\text { Business Groups }\end{array}$ & 391 & 20 \\
\hline 2 & Demirag, I.; Serter, M. & 2003 & $\begin{array}{l}\text { Corporate Governance: An } \\
\text { International Review }\end{array}$ & Ownership Patterns and Control in Turkish Listed Companies & 32 & 3 \\
\hline 3 & Cestone, G.; Fumagalli, C. & 2005 & Rand Journal of Economics & The strategic impact of resource flexibility in business groups & 33 & 4 \\
\hline 5 & Almeida, H.V.; Wolfenzon, D. & 2006 & Journal of Finance & $\begin{array}{l}\text { A Theory of Pyramidal Ownership and Family Business } \\
\text { Groups }\end{array}$ & 216 & 37 \\
\hline 10 & $\begin{array}{l}\text { Bae, G.S.; Youngsoon, S.C.; Jun-Koo, } \\
\text { K. }\end{array}$ & 2008 & The Review of Financial Studies & $\begin{array}{l}\text { Intragroup Propping: Evidence from the Stock-Price Effects of } \\
\text { Earnings Announcements by Korean Business Groups }\end{array}$ & 43 & 4 \\
\hline 12 & Levy, M. & 2009 & $\begin{array}{l}\text { Corporate Governance: An } \\
\text { International Review }\end{array}$ & Control in Pyramidal Structures & 22 & 4 \\
\hline 13 & Dow, S.; McGuire, J. & 2009 & Journal of Banking \& Finance & $\begin{array}{l}\text { Propping and tunneling: Empirical evidence from Japanese } \\
\text { keiretsu }\end{array}$ & 25 & 2 \\
\hline 14 & Bhaumik, S.; Gregoriou, A. & 2010 & $\begin{array}{l}\text { Journal of Chinese Economic and } \\
\text { Business Studies }\end{array}$ & $\begin{array}{l}\text { "Family" ownership, tunneling and earnings management: A } \\
\text { review of the literature }\end{array}$ & 25 & 3 \\
\hline 17 & $\begin{array}{l}\text { Almeida, H.V.; Park, S.Y.; } \\
\text { Subrahmanyam, M.G.; Wolfenzon, D. }\end{array}$ & 2011 & Journal of Financial Economics & $\begin{array}{l}\text { The structure and formation of business groups: Evidence from } \\
\text { Korean chaebols }\end{array}$ & 65 & 16 \\
\hline 20 & Masulis, R.; Pham, P.K.; Zein, J. & 2011 & The Review of Financial Studies & $\begin{array}{l}\text { Family Business Groups around the World: Financing } \\
\text { Advantages, Control Motivations, and Organizational Choices }\end{array}$ & 86 & 16 \\
\hline 29 & Bena, J.; Ortiz-Molina, H. & 2013 & Journal of Financial Economics & Pyramidal ownership and the creation of new firms & 8 & 4 \\
\hline 30 & Chung, H-M. & 2013 & Asia Pacific Journal of Management & $\begin{array}{l}\text { The role of family management and family ownership in } \\
\text { diversification: The case of family business groups }\end{array}$ & 11 & 3 \\
\hline 32 & $\begin{array}{l}\text { Byun, H-Y.; Choi, S.; Hwang, L-S.; } \\
\text { Kim, R.G. }\end{array}$ & 2013 & Journal of Corporate Finance & $\begin{array}{l}\text { Business group affiliation, ownership structure, and the cost of } \\
\text { debt }\end{array}$ & 19 & 3 \\
\hline 37 & Gopalan, R.; Nanda, V.; Seru, A. & 2014 & Review of Financial Studies & $\begin{array}{l}\text { Internal Capital Market and Dividend Policies: Evidence from } \\
\text { Business Groups }\end{array}$ & 13 & 4 \\
\hline 38 & $\begin{array}{l}\text { Buchuk, D.; Larrain, B.; Muñoz, F.; } \\
\text { Urzúa, F.I. }\end{array}$ & 2014 & Journal of Financial Economics & $\begin{array}{l}\text { The internal capital markets of business groups: Evidence from } \\
\text { intra-group loans }\end{array}$ & 30 & 6 \\
\hline
\end{tabular}

Legend: Id - article identification; GCS - Global Citation Score; LCS - Local Citation Score.

Source: Own elaboration based on HistCite ${ }^{\mathrm{TM}}$ 
To verify the co-citation of authors, we established the total counting method (each cocitation has the same weight) and a minimum number of citations by authors equal to 25 , based on 1,555 authors. It is worth mentioning that the nodes of the network are represented by the first author of each article in the set of references cited in the textual corpus. With the defined criteria, 16 authors presented ties between them.

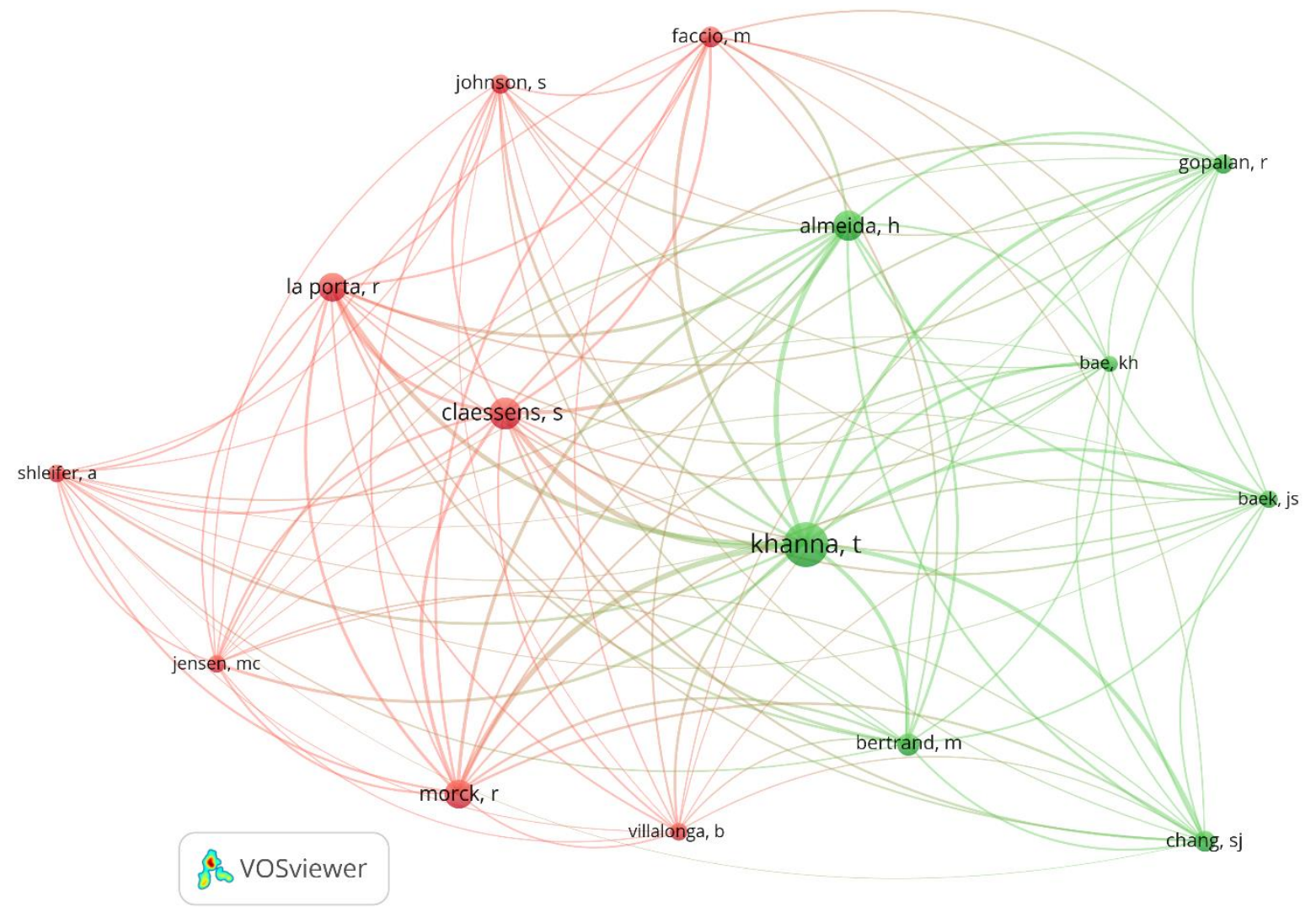

Figure 6. Co-citation of cited authors

Source: VOSviewer - Elaborated by the authors

The results report that the formulation of 2 clusters: Cluster 1 (C1): red color and Cluster 2 (C2): green color, which are shown in Figure 6. The thickness of the nodes is proportional to the frequency of citations received by the co-cited authors, and the straight segments represent the relations between the authors. From the analysis of the clusters, it is possible to identify the approximation of the authors from the citing articles. Thus, observing who are the most influential authors in a field of research.

In the first cluster (C1), eight co-cited authors are visualized (Claessens, S., Faccio, M., Jensen, MC, Johnson, S., La Porta, R., Morck, R., Shleifer, A. Villalonga, B.). The highest levels of citation and bond strength are for Claessens, S. (88 citations and 1,181 connections), Morck, R. (77 citations and 1,062 connections) and La Porta (76 citations and 912 connections). 
In the second grouping (C2) we have the presence of 7 co-cited authors (Almeida, H., Bae, KH, Baek, JS, Bertrand, M, Chang, SJ, Gopalan, R, Khanna, T). In this cluster, two other authors stand out for the levels of citation and interconnection with the others: Khanna, T. (177 citations and 2,079 connections), Almeida, H. (84 citations and 1,160 connections) and Bertrand (46 citations and 720 connections).

Many links between the authors of cluster 1 and cluster 2 are visualized. These links also expand, since there is also interaction among all authors analyzed. In the first group (C1) some authors usually emphasize in their work, issues related to agency relations, legal protection of minority shareholders, and deviations of rights. Authors like Johnson, S., La Porta, R., and Shleifer, A. have a joint work entitled "Tunneling," published in the American Economic Review in the year 2000, which made an important contribution to the literature. La Porta, R. and Shleifer, A., can also be considered highly connected since they have several studies published jointly, some cited in the introduction and theoretical reference of this literature review.

In the second grouping $(\mathrm{C} 2)$, the author with the highest connection in the network is highlighted (Khanna, T). Moreover, he has articles, which emphasize business groups, bringing contributions to their understanding in emerging markets. It is also noticed that the papers that cite this author, also mention the other authors of the cluster (C2), as a function of theoretical approximations. We inferred that the authors produce articles on the topic of Tunneling in business groups, and in some cases, focus on the Asian markets, such as the Korean Business Groups. From the co-citation of authors, can notice which are the most representative for the field of studies under analysis and, which are interconnected, from the citations together in the literature.

Further, proceeding the citation analysis, the method of document coupling was adopted, considering a minimum number of 10 citations, which generated 25 coupling documents in total. 


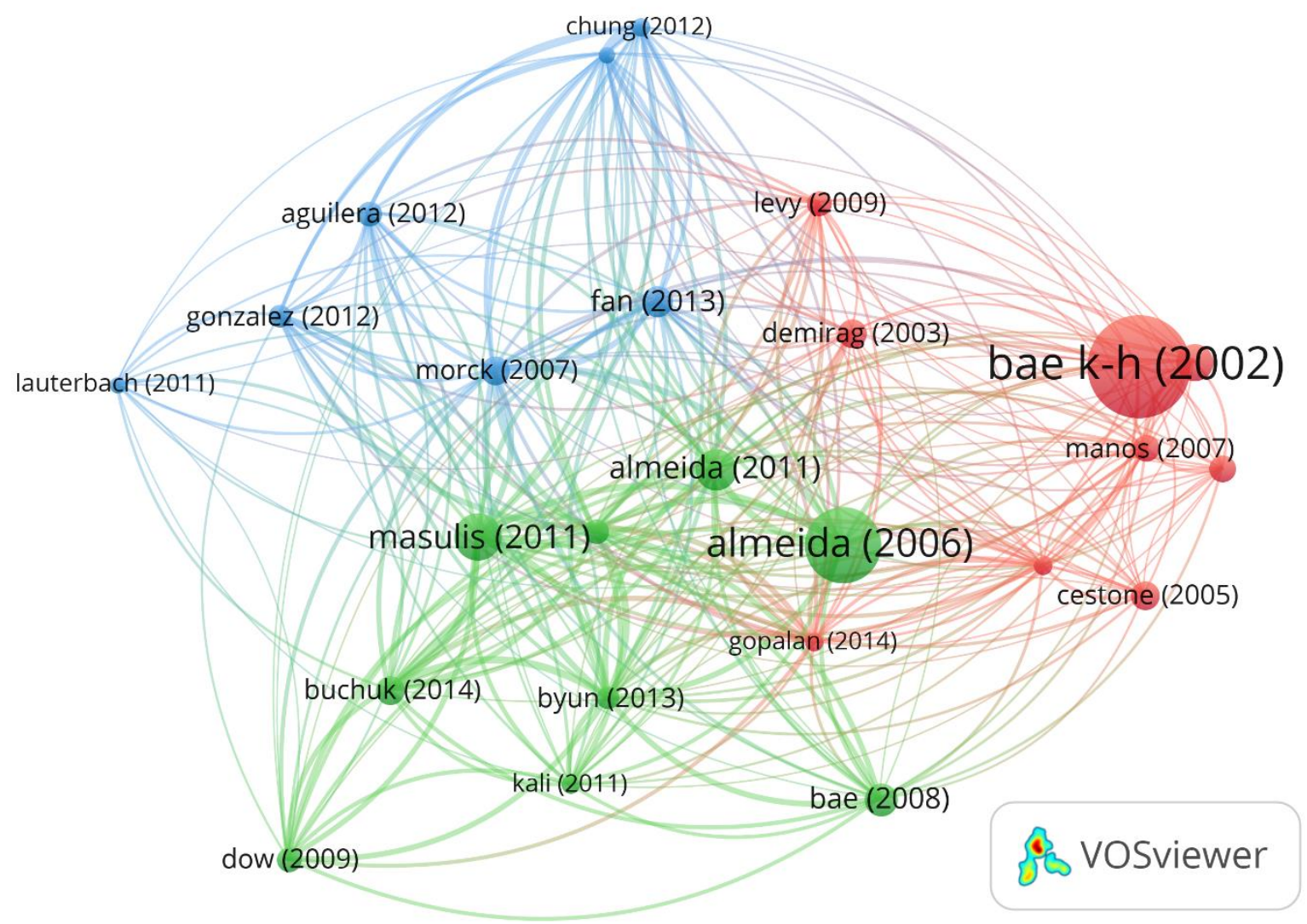

Figure 7. Bibliographic coupling of documents

Source: VOSviewer - Elaborated by the authors

Moreover, by observing Figure 7 , it is possible to verify that the most intensively coupled authors are distributed in three clusters: Cluster 1 (C1) represented by red color and nine documents; Cluster 2 (C2) in green color and nine documents; and Cluster 3 (C3) in dark blue color and seven documents. In this case, the thickness of the nodes is based on the total number of citations received by the documents. In $\mathrm{C} 1$, the documents with greater coupling were of Almeida (2006) with 216 citations and 176 connections and of Masulis (2011) with 86 citations and 210 connections. Only the quotations from Almeida (2006) represent $41 \%$ of the total citations in this cluster. It should be noted, concerning connectivity that the articles that make up the first grouping have ties of connections greater than 90 , demonstrating that they are coupled when referencing joint publications. The work with the greatest number of connections (227) is from Bhaumik (2010).

As for the second cluster (C2), we highlight the representativeness of Bae's article (2002), with 391 citations (64\% of the total) and 50 connections. However, the paper with the greatest number of connections (122) is from Gopalan (2014), revealing its theoretical proximity to the other works. In cluster 3, we observed seven coupled documents, which have 
a smaller number of citations than the documents allocated in $\mathrm{C} 1$ and $\mathrm{C} 2$. The document in highlight is Fan (2013) with 35 citations and 117 connections. The number of citations of this work represents $24 \%$ of the total of the cluster. The greatest connectivity is the article of Morck (2007), corresponding to 169 connections (23\% of the total of C3).

\subsection{Evaluation of Reputation of Journals}

Based on the HistCite ${ }^{\mathrm{TM}}$ (Garfield, 2009) results, Bradford's Law procedures were mapped, identifying the total of journals, the number of papers in each, and the productivity indicators. Regarding the bibliometric indicators, the journal title, the SJR citation quarts, the number of articles published in each journal $\left(\mathrm{N}^{\circ}\right)$, the SJR Index, and the $\mathrm{H}$ index were mapped for 2017 (see Table 3).

Table 3. Bibliometric indicators of the textual corpus' journals

\begin{tabular}{|c|c|c|c|c|c|c|}
\hline$\stackrel{\mathscr{E}}{\tilde{\Xi}}$ & Title & $\begin{array}{c}\text { SJR } \\
\mathbf{Q}\end{array}$ & $\mathbf{N}^{\mathbf{o}}$ & $\begin{array}{c}\text { SJR } \\
\text { Index }\end{array}$ & $\underset{\text { Index }}{\mathbf{H}}$ & Country \\
\hline \multirow{2}{*}{$\bar{N}$} & Journal of Corporate Finance & Q1 & 4 & 1,46 & 77 & Netherlands \\
\hline & Emerging Markets Finance and Trade & Q2 & 5 & 0,40 & 24 & United States \\
\hline \multirow{10}{*}{ N } & Journal of Finance & Q1 & 2 & 18,3 & 249 & United Kingdom \\
\hline & Review of Financial Studies & Q1 & 3 & 14,2 & 145 & United Kingdom \\
\hline & Journal of Financial Economics & Q1 & 3 & 12,5 & 206 & Netherlands \\
\hline & Journal of Family Business Strategy & Q1 & 3 & 1,28 & 27 & Netherlands \\
\hline & Asia Pacific Journal of Management & Q1 & 3 & 1,19 & 60 & United States \\
\hline & Corporate Governance - An International Review & Q1 & 3 & 1,14 & 62 & United Kingdom \\
\hline & Emerging Markets Review & Q1 & 2 & 1,11 & 39 & Netherlands \\
\hline & Journal of Comparative Economics & Q2 & 2 & 0,99 & 69 & United States \\
\hline & BRQ-Business Research Quarterly & Q1 & 2 & 0,50 & 12 & Netherlands \\
\hline & Asia-Pacific Journal of Financial Studies & Q3 & 3 & 0,22 & 9 & United Kingdom \\
\hline \multirow{15}{*}{$\widehat{N}$} & Strategic Management Journal & Q1 & 1 & 8,01 & 232 & United States \\
\hline & RAND Journal of Economics & Q1 & 1 & 3,65 & 92 & United States \\
\hline & Small Business Economics & Q1 & 1 & 1,94 & 98 & Netherlands \\
\hline & Journal of World Business & Q1 & 1 & 1,72 & 87 & United Kingdom \\
\hline & Journal of Law Economics and Organization & Q1 & 1 & 1,59 & 60 & United Kingdom \\
\hline & Journal of Banking and Finance & Q1 & 1 & 1,50 & 126 & Netherlands \\
\hline & Journal of Economic Surveys & Q1 & 1 & 1,46 & 76 & United Kingdom \\
\hline & Journal of Business Ethics & Q1 & 1 & 1,28 & 132 & Netherlands \\
\hline & Pacific Basin Finance Journal & Q1 & 1 & 1,13 & 43 & Netherlands \\
\hline & Journal of Economics and Management Strategy & Q1 & 1 & 1,11 & 58 & United Kingdom \\
\hline & International Business Review & Q1 & 1 & 1,01 & 73 & United Kingdom \\
\hline & Advances in Strategic Management & Q1 & 1 & 0,97 & 24 & United Kingdom \\
\hline & Journal of Business Finance \& Accounting & Q1 & 1 & 0,91 & 60 & United Kingdom \\
\hline & Finance Research Letters & Q2 & 1 & 0,56 & 21 & Netherlands \\
\hline & Journal of Management and Organization & Q1 & 1 & 0,54 & 25 & United Kingdom \\
\hline
\end{tabular}




\begin{tabular}{l|c|c|c|c|c} 
Management Decision & Q1 & 1 & 0,54 & 77 & United Kingdom \\
Journal of Multinational Financial Management & Q2 & 1 & 0,53 & 34 & Netherlands \\
Business History & Q1 & 1 & 0,52 & 27 & United Kingdom \\
Quarterly Review of Economics and Finance & Q2 & 1 & 0,50 & 42 & Netherlands \\
Journal of Economics and Business & Q1 & 1 & 0,50 & 43 & Netherlands \\
Journal of Management and Governance & Q2 & 1 & 0,44 & 41 & Netherlands \\
Global Finance Journal & Q3 & 1 & 0,37 & 26 & Netherlands \\
Corporate Governance (Bingley) & Q2 & 1 & 0,34 & 43 & United Kingdom \\
Journal of Contemporary Accounting and Economics & Q3 & 1 & 0,33 & 12 & Netherlands \\
Journal of Asia Business Studies & Q2 & 1 & 0,24 & 8 & United Kingdom \\
Enterprise and Society & Q3 & 1 & 0,24 & 21 & United Kingdom \\
Asian Review of Accounting & Q3 & 1 & 0,22 & 15 & United Kingdom \\
Journal of Chinese Economic and Business Studies & Q3 & 1 & 0,21 & 11 & United States \\
Journal of Applied Business Research & Q3 & 1 & 0,20 & 14 & United States \\
International Journal of Managerial Finance & Q3 & 1 & 0,20 & 16 & United Kingdom \\
\hline
\end{tabular}

aJournals ranked by the higher to lower SJR index

Source: Elaborated by the authors

We report that the subjects under study have good coverage, and comprise of 42 different journals. Many of these journals focus on business, economics, and finance. The distribution by quartiles shows that most journals (26) are classified in the first quartile since, in the second and third quartiles, there are eight periodicals in each.

The core consists of two journals, the Emerging Markets Finance, and Trade with five articles published on the subject and the Journal of Corporate Finance, with the publication of 4 articles. It can be concluded that zone 1 represents about $14 \%$ of the total articles of the textual corpus. Even with a small number of journals in this area (only two), it can still be concluded that it is the most representative in terms of production.

In the second zone, ten journals are present, with a total of 26 articles representing $40 \%$ of the total. Most of these journals are in the first quartile and also your scope focused on economic and financial areas. In the third and last zone, there are a greater number of journals (30), each having an article published on the topic, which represents $46 \%$ of the total. Thus, it is noticed that in this zone, there is a greater number of periodicals than the others, demonstrating that the publication is dispersed.

Considering the indicators presented in the previous table, we have the SJR (SCImago Journal Rank) indicator and H-index. The SJR measures the impact, influence or prestige of journals by means of the average number of weighted citations recorded in the selected year, and by the documents published in the journal three years earlier. The $\mathrm{H}$-index representing the number of articles in the journal (h) that received at least ' $h$ ' citations throughout the period. Both indicators are developed by Scimago Institutions Rankings and are listed for the year 
2017. Journal citation measures are important for bibliometric studies, because show different aspects, such as quality or prestige as perceived by scholars (Glänzel \& Moed, 2002).

The highest levels of SJR were attributed to three periodicals that compose zone 2, being the Journal of Finance, the Review of Financial Studies and the Journal of Financial Economics. As for the $\mathrm{H}$ index, the Journal of Finance also has the highest value, with an indicator of 249. The same is followed by the Strategic Management Journal (232) and the Journal of Financial Economics (206). At the core, the journal with the highest scores on these indices is the Journal of Corporate Finance, which has a SJR of 1.46 and an $\mathrm{H}$ index equal to 77 . The interpretation of the results described in $\mathrm{H}$ index, taking as an example the Journal case of Finance, whose value was equal to 249 , shows this journal had 249 of its articles quoted at least 249 times, which reflects a high reputation of this scientific magazine.

A total of 16 publishers are noteworthy, with the highest productivity being found in the Elsevier group, which is responsible for the publication of 16 periodicals (38\% of the total) and is present in all three journals countries. Following is Emerald Group Publishing Ltd., with six journals and Blackwell Publishing Inc. with five journals. Thus, it can be said these publishers, when placed together, represent $64 \%$ of the total analyzed in the textual corpus.

\subsection{Word co-occurrence analysis}

The free software IRAMUTEQ (Interface for Multi-Dimensional Analysis of Texts and Questionnaires) was used, which is anchored in software R and allows different forms of textual corpus analysis (Ratinaud \& Marchand, 2012). We considered the cloud of words, and the factorial correspondence analysis. The word cloud, with a frequency indicator, will show those that have importance in the textual corpus. The factorial correspondence analysis the words of the textual corpus in a factorial plane, distributing them in classes. Thus, complementary analyzes can be considered when they demonstrate different characteristics. For the word cloud formulation (Figure 8), a minimum co-occurrence of 20 was considered, to illustrate the more frequent words in simple lexical analysis. 


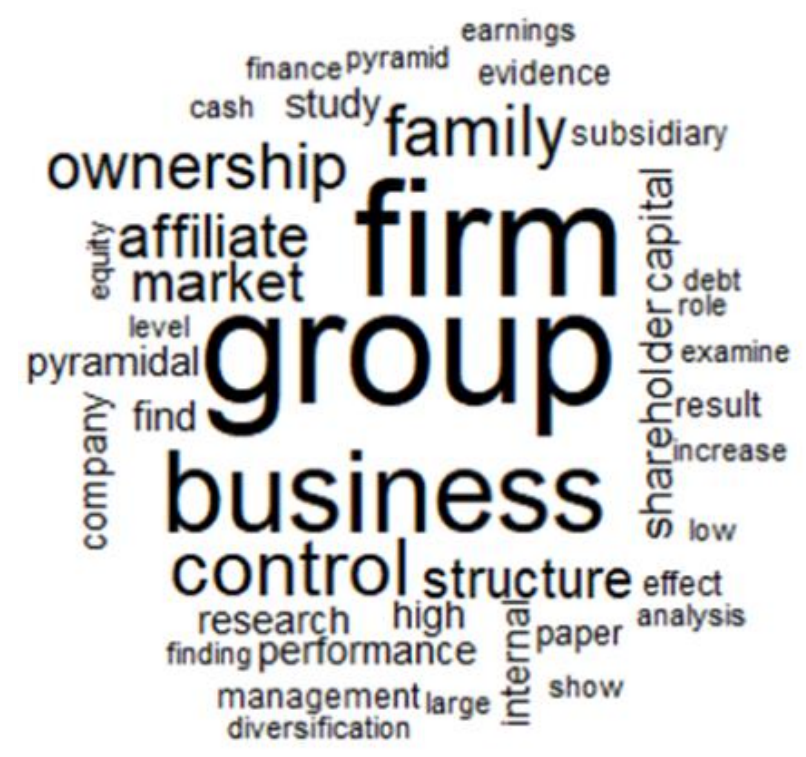

Figure 8. Word cloud

Source: IRAMUTEQ - Elaborated by the authors

We noted that out of 9,719 occurrences of the textual corpus. We selected those that had at least 20 co-occurrences (frequency of occurrence), resulting in 41 words, which are illustrated in the cloud. The emphasis is on "group," "firm," and "business." Each of the words "group" and "firm" represents $12 \%$ of the total occurrences of the cloud, while the word "business" represents $8 \%$ of that total. In general, the terms "business" and "groups" are worked together, characterizing firms with ties to each other. Moreover, it should be noted that the words referring to the pyramidal structure did not obtain this prominence, being related to the themes of control structure and ownership, which appear more frequently in the cloud. Still, it is worth noticing the presence of the element "family" ( $4 \%$ of the total of the cloud), characterizing the literature on family business groups.

In addition, we performed the factorial correspondence analysis by the Reinert method. It represents the distribution of word classes in a factorial plane and with the representation of Euclidean distances that can identify the differences or similarities between the axes (up/down and left/right). For the estimation of results, 207 text segments were considered, representing $76.10 \%$ of the total (272 segments). 


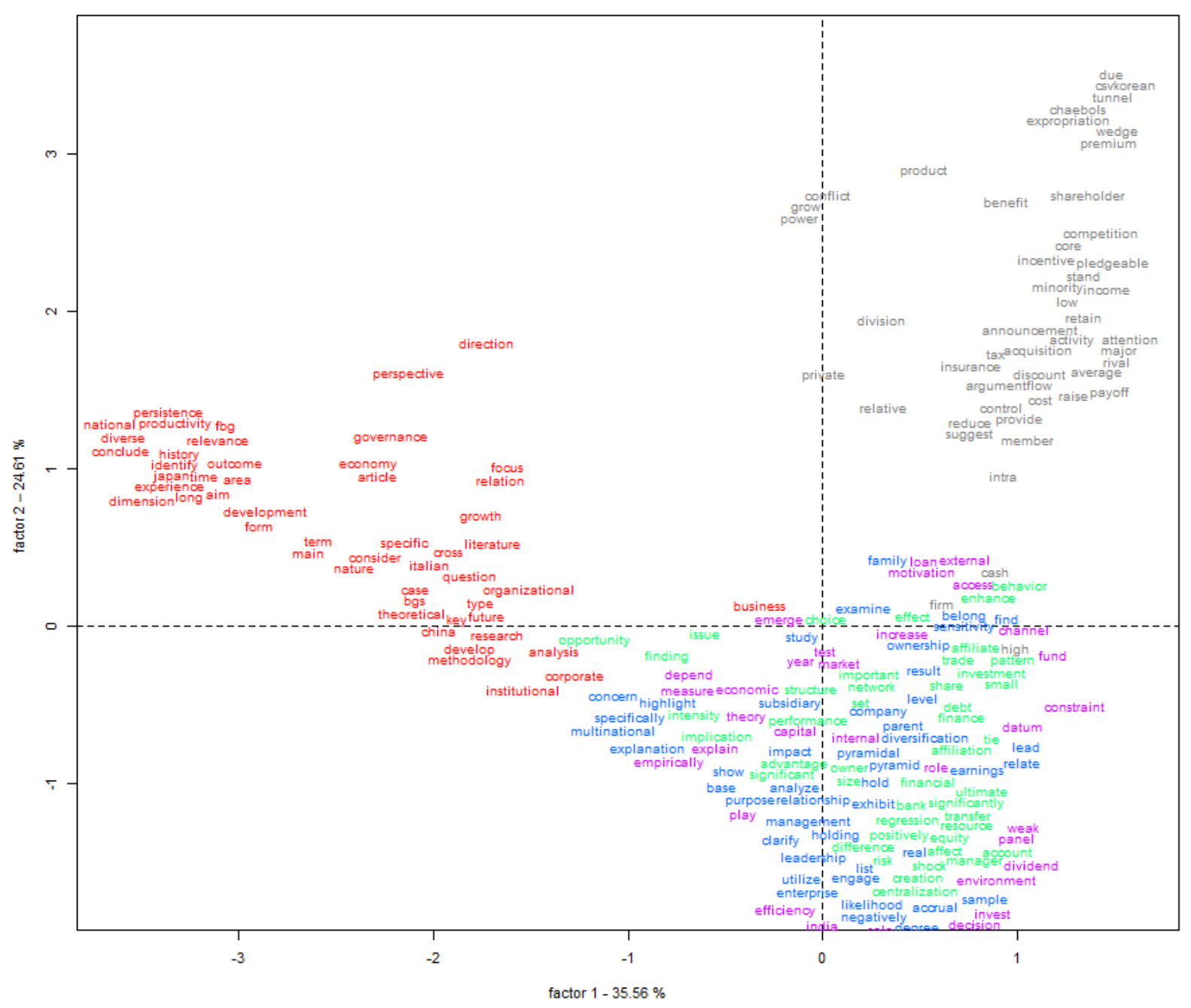

Figure 9. Factorial Correspondence Analysis Source: IRAMUTEQ - Elaborated by the authors

In Figure 9, it is observed the constitution of five classes of words, with class 1 represented by red color, two by gray, three by green, four by blue, and five by purple. These are distributed in a factorial plan composed of two factors, which together have a cumulative percentage of $60.17 \%$. Factor 1 is represented by the $y$-axis $(35.56 \%)$ and factor 2 by the $x$-axis (24.61\%). It is shown that class 1 (red) is closer to factor 2 and the others (2, 3, 4 and 5) are aligned to the right side of the plane, close to factor 1 .

In order to estimate the incidence of words in each class, the first 50 points per class were defined to explore the most relevant aspects of the textual corpus. It is observed that around the central axis we have the presence of words like "business," "emerge," "study," "choice" and "examine," which are part of different classes but represent the common part to 
the research corpus, that is, more homogeneous. It should be emphasized that these are words linked to the nature of studies, such as the focus on business and emerging markets.

The other results show that the words of classes 1 and two are distributed in two distinct quadrants, while classes 3, 4, and 5 are very close. In class 1, we can notice the grouping of a set of words that refer to economic, corporate governance, and development issues. This class can be seen as distinct from class 2, which represents a dimension at the firm level. In class 2, there is the grouping of words that characterize the shareholder, including the expropriation of minority shareholders.

The grouping of classes 3, 4, and 5 shows the differing relationships, compared to the other classes. From the distances of the graph, it is observed that these three classes are together, approaching a little of class 1 (red color). As for the type of word found in each class, we note that they are varied. It should be emphasized the presence of aspects related to the pyramidal structure and business groups, such as internal capital markets and diversification.

\section{Conclusion and avenues for future research}

This article aimed to analyze the results of the research in pyramidal structures within the business groups, based on three different (but complementary) citation analysis methods, to be mapped in a consistent manner.

Five classes of words were listed, which represent the conceptual structure of the corpus. However, the formation of two main axes, referring to classes 1 and 2, are foreseen. The first axis should focus on the formation of business groups, investigating issues of group identity, governance, and development of these in the markets. Already, the second axis represents the research at the firm level. For this, the investigation of internal elements (control, shareholder, and tunneling) is emphasized. From this perspective, it can be concluded that pyramidal structures were not included in these two main axes. However, they are related to the second class, in the sense of associating with tunneling studies and expropriation of minority shareholders.

We infer as a conceptual framework that searches in pyramidal structures are contained in the field of business groups since they represent a form of organization and representation of ownership and control. The themes of corporate governance, tunneling, and internal capital markets have been recurrent in the articles. The most representative approach is empirical, reporting mostly results from firms in Asian countries. We identify as a theoretical gap the 
analysis of the political connections and the social role of the business groups. Few papers discussed the interaction of business groups with the government.

We suggest, therefore, a research agenda that contemplates political and social elements in the relation of business groups and pyramid structures. We report as an example of the concept of rent-seeking, derived from the performance function as a search for economic income from the manipulation of the political and social environment. In the social sphere, pyramids are net chains, and it is important to clarify how groups and pyramids can be positive or negative for social well-being. Another item on the research agenda is the enlargement of the countries analyzed. Most of the work uses the Asian and European markets. We consider it important to analyze different countries, enabling more comprehensive practical comparisons.

As limitations, we highlight the multidisciplinarity of the business groups theme, opting to explore it in the areas of Business, Management, Accounting, Economics, Econometrics, and Finance. Even if the systematic review identifies characteristics of the field, such as authors, coauthors, and journals, it does not replace the extensive reading of the publications, an action not performed in this research.

\section{References}

Almeida, H., Park, S. Y., Subrahmanyam, M. G., \& Wolfenzon, D. (2011). The structure and formation of business groups: Evidence from Korean chaebols. Journal of Financial Economics, 99(2), 447-475. https://doi.org/10.1016/j.jfineco.2010.08.017

Almeida, H., \& Wolfenzon, D. (2006). A Theory of Pyramidal Ownership. The Journal of Finance, 56(6), 2637-2680. https://doi.org/10.1111/j.1540-6261.2006.01001.x

Bae, G. S., Cheon, Y. S., \& Kang, J. K. (2008). Intragroup propping: Evidence from the stock-price effects of earnings announcements by korean business groups. Review of Financial Studies, 21(5), 2015-2060. https://doi.org/10.1093/rfs/hhn055

Bae, K. H., Kang, J. K., \& Kim, J. M. (2002). Tunneling or value addition? Evidence from mergers by Korean business groups. The Journal of Finance, LVII(6).

Bebchuk, L. A., Kraakman, R., \& Triantis, G. G. (2000). Ownership and Dual Class Equity: The Mechanisms and Agency Costs of Separating Control from Cash-Flow Rights. In Concentrated Corporate Ownership (pp. 445-460). University of Chicago Press.

Bena, J., \& Ortiz-Molina, H. (2013). Pyramidal ownership and the creation of new firms. Journal of Financial Economics, 108(3), 798-821. https://doi.org/10.1016/j.jfineco.2013.01.009 
Bennedsen, M., Fan, J. P. H., Jian, M., \& Yeh, Y. H. (2015). The family business map: Framework, selective survey, and evidence from Chinese family firm succession. Journal of Corporate Finance, 33, 212-226.

https://doi.org/10.1016/j.jcorpfin.2015.01.008

Bertrand, M., Mehta, P., \& Mullainathan, S. (2002). Ferreting Out Tunneling : An Application to Indian Business. The Quarterly Journal of Economics, 117(1), 121-148.

Bertrand, M., \& Mullainathan, S. (2003). Pyramids. Journal of the European Economic Association, 1(2-3), 478-473.

Bhaumik, S. K., \& Gregoriou, A. (2010). "Family" ownership, tunnelling and earnings management: A review of the literature. Journal of Economic Surveys, 24(4), 705-730. https://doi.org/10.1111/j.1467-6419.2009.00608.x

Bradford, S. C. (1934). Sources of Information on Specific Subjects. Engineering, 137, 8586.

Buchuk, D., Larrain, B., Muñoz, F., \& Urzúa I., F. (2014). The internal capital markets of business groups: Evidence from intra-group loans. Journal of Financial Economics, 112(2), 190-212. https://doi.org/10.1016/j.jfineco.2014.01.003

Byun, H. Y., Choi, S., Hwang, L. S., \& Kim, R. G. (2013). Business group affiliation, ownership structure, and the cost of debt. Journal of Corporate Finance, 23, 311-331. https://doi.org/10.1016/j.jcorpfin.2013.09.003

Castillo-Vergara, M., Alvarez-Marin, A., \& Placencio-Hidalgo, D. (2018). A bibliometric analysis of creativity in the field of business economics. Journal of Business Research, 85(December 2017), 1-9. https://doi.org/10.1016/j.jbusres.2017.12.011

Cestone, G., \& Fumagalli, C. (2005). The strategic impact of resource flexibility in business groups. RAND Journal of Economics, 36(1), 193-214.

Chen, G., Firth, M., Gao, D. N., \& Rui, O. M. (2006). Ownership structure, corporate governance, and fraud: Evidence from China. Journal of Corporate Finance, 12(3), 424448. https://doi.org/10.1016/j.jcorpfin.2005.09.002

Chung, C.-N. (2004). Institutional Transition and Cultural Inheritance. International Sociology, 19(1), 25-50. https://doi.org/10.1177/0268580904040919

Chung, H. M. (2013). The role of family management and family ownership in diversification: The case of family business groups. Asia Pacific Journal of Management, 30(3), 871-891. https://doi.org/10.1007/s10490-012-9284-X

Claessens, S., Djankov, S., \& Lang, L. H. . (2000). The separation of ownership and control in East Asian Corporations. Journal of Financial Economics, 58(1-2), 81-112. 
https://doi.org/10.1016/S0304-405X(00)00067-2

Colpan, A. M., Hikino, T., \& Lincoln, J. R. (2010). The Oxford Handbook of Business Groups. New York: Oxford University Press Inc.

Cuervo-Cazurra, A. (2006). Business groups and their types. Asia Pacific Journal of Management, 23(4), 419-437. https://doi.org/10.1007/s10490-006-9012-5

Demirag, I., \& Serter, M. (2003). Ownership Patterns and Control in Turkish Listed Companies. Corporate Governance: An International Review, 11(1), 40-51. https://doi.org/10.1111/1467-8683.00300

Dow, S., \& McGuire, J. (2009). Propping and tunneling: Empirical evidence from Japanese keiretsu. Journal of Banking and Finance, 33(10), 1817-1828. https://doi.org/10.1016/j.jbankfin.2009.05.012

Faccio, M., Lang, L. H. P., \& Young, L. (2001). American Economic Association. The American Economic Review, 91(1), 54-78. https://doi.org/10.1057/9780230226203.0037

Garfield, E. (2009). From the science of science to Scientometrics visualizing the history of science with HistCite software. Journal of Informetrics, 3, 1-7. https://doi.org/10.1016/j.joi.2009.03.009

Garfield, E., Pudovkin, A. I., \& Istomin, V. S. (2003). Why do we need algorithmic historiography? Journal of the American Society for Information Science and Technology, 54(5), 400-412. https://doi.org/10.1002/asi.10226

Glänzel, W., \& Moed, H. F. (2002). Journal impact measures in bibliometric research. Scientometrics, 53(2), 171-193. https://doi.org/https://doi.org/10.1023/A:1014848323806

Gopalan, R., Nanda, V., \& Seru, A. (2014). Internal capital market and dividend policies: Evidence from business groups. Review of Financial Studies, 27(4), 1102-1142. https://doi.org/10.1093/rfs/hhu004

Granovetter, M. (1994). Business Groups. In Handbook of economic sociology. Princeton University Press.

Granovetter, M. (2005). Business Groups and Social Organization. In N. Smelser \& R. Swedberg (Eds.), The handbook of economic sociology. New York.

Holmén, M., \& Högfeldt, P. (2009). Pyramidal Discounts: Tunneling or Overinvestment? International Review of Finance, 9(1-2), 133-175. https://doi.org/10.1111/j.14682443.2009.01088.x

Jensen, C., \& Meckling, H. (1976). Theory of the firm: managerial behavior, agency costs and ownership structure. Journal of Financial Economics, 3, 305-360. 
https://doi.org/10.1016/0304-405X(76)90026-X

Johnson, S., La Porta, R., Lopez-de-Silanes, F., \& Shleifer, A. (2000). Tunneling. American Economic Review, 90(2), 22-27. https://doi.org/10.1257/aer.90.2.22

Kessler, M. M. (1963). Bibliographic coupling between scientific articles. American Documentation, 24, 123-131.

Khanna, T. (2000). Business groups and social welfare in emerging markets: Existing evidence and unanswered questions. European Economic Review, 44(4-6), 748-761. https://doi.org/10.1016/S0014-2921(99)00059-8

Khanna, T., \& Palepu, K. (2000). Is Group Affiliation Profitable in Emerging Markets? An Analysis of Diversified Indian Business Groups. The Journal of Finance, LV(2), 867891.

Khanna, T., \& Rivkin, J. W. (2001). Estimating the Performance Effects of Networks in Emerging Markets. Strategic Management Journal, 22(July 2000), 45-74. https://doi.org/10.2139/ssrn.156489

Khanna, T., \& Yafeh, Y. (2007). Business Groups Paragons in Emerging or Parasites? American Economic Association, 45(2), 331-372.

La Porta, R., Lopez-de-silanes, F., \& Shleifer, A. (1999). Corporate Ownership around the World Corporate Ownership Around the World. Journal of Finance, 54(2), 471-517.

La Porta, R., Lopez-de-Silanes, F., \& Shleifer, A. (1998). Law and Finance. Journal of Political Economy, 106(6), 1113-1155.

La Porta, R., Lopez-de-silanes, F., Shleifer, A., \& Vishny, R. (2000). Investor protection and corporate governance. Journal of Financial Economics, 58, 3-27. https://doi.org/10.1016/S0304-405X(00)00065-9

La Porta, R., Lopez-de-Silanes, F., Shleifer, A., \& Vishny, R. (2002). Investor protection and corporate valuation. The Journal of Finance, LVII(3), 1147-1170.

La Porta, R., Lopez-de-Silanes, F., Shleifer, A., \& Vishny, R. W. (1997). Legal Determinants of External Finance. The Journal of Finance, 52(3), 1131-1150.

https://doi.org/10.1111/j.1540-6261.1997.tb02727.x

Leff, N. H. (1978). Industrial Organization and Entrepreneurship in the Developing Countries: The Economic Groups. Economic Development and Cultural Change, 26(4), 661-675. https://doi.org/10.1086/451052

Levy, M. (2009). Control in pyramidal structures. Corporate Governance: An International Review, 17(1), 77-89. https://doi.org/10.1111/j.1467-8683.2008.00719.x

Lotka, A. J. (1926). The frequency distribution of scientific productivity. Journal of the 
Washington Academy of Sciences, 16(12), 317-323. Retrieved from http://www.jstor.org/stable/24529203

Marshakova, I. V. (1981). Citation networks in information science. Scientometrics, 3(1), 1325. https://doi.org/10.1007/BF02021861

Masulis, R. W., Pham, P. K., \& Zein, J. (2011). Family business groups around the world: Financing advantages, control motivations, and organizational choices. Review of Financial Studies, 24(11), 3556-3600. https://doi.org/10.1093/rfs/hhr052

Morck, R. K. (2007). A history of corporate governance around the world: family business groups to professional managers. Chicago: The University of Chicago Press.

Ratinaud, P., \& Marchand, P. (2012). Application de la méthode ALCESTE aux "gros" corpus et stabilité des "mondes lexicaux": analyse du "CableGate" avec IRAMUTEQ. Actes Des 1lèmes Journées Internationales d'Analyse Des Données Textuelles (JADT), $835-844$.

Riyanto, Y. E., \& Toolsema, L. A. (2008). Tunneling and propping: A justification for pyramidal ownership. Journal of Banking \& Finance, 32(10), 2178-2187. https://doi.org/10.1016/j.jbankfin.2007.12.044

Shleifer, A., \& Wolfenzon, D. (2002). Investor protection and equity markets. Journal of Financial Economics, 66, 3-27.

Siddiqui, S. S. (2015). The association between corporate governance and firm performance a meta-analysis. International Journal of Accounting and Information Management, 23(3), 218-237. https://doi.org/http://dx.doi.org/10.1108/MRR-09-2015-0216

Small, H. (1973). Co-citation in the Scientific Literature : A New Measure of the Relationship Between Two Documents. Journal of the American Society for Information Science, 24(4), 265-269.

Tranfield, D., Denyer, D., \& Smart, P. (2003). Towards a methodology for developing evidence-informed management knowledge by means of systematic review. British Journal of Management, 14, 207-222.

Vallaster, C., Kraus, S., Merigó Lindahl, J. M., \& Nielsen, A. (2019). Ethics and entrepreneurship: A bibliometric study and literature review. Journal of Business Research, 99(February), 226-237. https://doi.org/10.1016/j.jbusres.2019.02.050

Van Eck, N. J., \& Waltman, L. (2010). Software survey: VOSviewer, a computer program for bibliometric mapping. Scientometrics, 84(2), 523-538. https://doi.org/10.1007/s11192009-0146-3

Wolfenzon, D. (1999). A Theory of Pyramidal Ownership. Retrieved from 
https://www.nber.org/papers/w11368.pdf

Yiu, D. W., Lu, Y., Bruton, G. D., \& Hoskisson, R. E. (2007). Business groups: An integrated model to focus future research: Review paper. Journal of Management Studies, 44(8), 1551-1579. https://doi.org/10.1111/j.1467-6486.2007.00735.x

Zipf, G. K. (1949). Human Behavior and the Principle of Least Effort: An introduction to Human Ecology. Massachusetts: Addison-Wesley Press.

Zupic, I., \& Čater, T. (2015). Bibliometric Methods in Management and Organization. Organizational Research Methods, 18(3), 429-472.

https://doi.org/10.1177/1094428114562629 